\title{
PROFIL KEMAMPUAN REPRESENTASI MATEMATIS SISWA SMP DITINJAU DARI SELF EFFICACY
}

\author{
Rina Dwi Setyawati, Ervia Bidra Ambarizka, Agung Handayanto \\ Universitas PGRI Semarang, Semarang
}

\begin{abstract}
Abstrak
Penelitian ini bertujuan untuk mengetahui profil kemampuan representasi matematis siswa SMP ditinjau dari self efficacy. Jenis penelitian ini merupakan penelitian kualitatif deskriptif. Subjek yang di ambil adalah 3 siswa kelas IX di SMP Negeri 2 Kaliwungu semester gasal tahun ajaran 2020/2021 yang masing-masing mempunyai self efficacy tinggi, self efficacy sedang, dan self efficacy rendah. Pengumpulan data yang dilakukan yaitu dengan skala self efficacy, tes tertulis, wawancara dan dokumentasi. Teknik analisis data dilakukan dengan 3 tahapan yaitu reduksi data, penyajian data, penarikan kesimpulan/verifikasi. Keabsahan data menggunakan triangulasi metode yaitu membandingkan hasil tes kemampuan representasi dengan hasil wawancara. Analisis dikembangkan berdasarkan indikator kemampuan representasi matematis dengan memperhatikan self efficacy yang dimiliki. Berdasarkan hasil analisis, diketahui bahwa subjek dengan self efficacy tinggi juga memiliki kemampuan representasi tinggi. Subjek dengan self efficacy sedang juga memiliki kemampuan representasi sedang. Subjek dengan self efficacy rendah juga memiliki kemampuan representasi rendah.
\end{abstract}

Kata kunci: kemampuan representasi matematis, self efficacy

\begin{abstract}
This study aims to determine the profile of the mathematical representation ability of junior high school students in terms of self-efficacy. The type of this research is descriptive qualitative. The subjects were 3 grade IX students at SMP Negeri 2 Kaliwungu in the odd semester of the 2020/2021 school year, each of whom had high self-efficacy, moderate self-efficacy, and low selfefficacy. Data collection was carried out using a self-efficacy scale, written tests, interviews, and documentation. The data analysis technique was executed in 3 stages, namely data reduction, data presentation, drawing conclusions / verification. The validity of the data used triangulation method, by comparing the results of the representation ability test with the results of the interview. The analysis is developed based on the indicator of mathematical representation ability by paying attention to the owned selfefficacy. Based on the results of the analysis, it is known that subject with high self-efficacy also has high representation abilities. Subject with moderate self-efficacy also has moderate representation abilities. Subject with low self-efficacy also has low representation skills.
\end{abstract}

Keywords: mathematical representation, self efficacy 


\section{PENDAHULUAN}

Matematika merupakan ilmu universal yang mendasari perkembangan teknologi modern dan membantu mengembangkan kemampuan atau daya berpikir manusia. Menurut Suyitno (Suyitno, 2016) mathematics is a queen of scienses atau matematika adalah ratu dari ilmu pengetahuan karena topik matematika dapat dikembangkan tanpa campur tangan ilmu lain dan mathematics is a servant of sciences yang berarti matematika adalah pelayan pengetahuan, karena matematika dibutuhkan oleh semua ilmu pengetahuan.Pembelajaran matematika merupakan salah satu pembelajaran yang dapat melatih dan mengembangkan kemampuan berpikir siswa (Annajmi, 2016). Mata pelajaran matematika bertujuan agar siswa memiliki kemampuan, yaitu: (1) Memahami konsep matematika, menjelaskan keter-kaitan antar konsep dan mengaplikasikan konsep atau algoritma, secara luwes, akurat, efisien, dan tepat, dalam pemecahan masalah, (2) Menggunakan penalaran pada pola dan sifat, melakukan manipulasi matematika dalam membuat generalisasi, menyusun bukti, atau menjelaskan gagasan dan pernyataan matematika, (3) Memecahkan masalah yang meliputi kemampuan memahami masalah, merancang model matematika, menyelesaikan model dan menafsirkan solusi yang diperoleh, (4) Mengomuni-kasikan gagasan dengan simbol, tabel, diagram, atau media lain untuk memperjelas keadaan atau masalah, dan (5) Memiliki sikap menghargai kegunaan matematika dalam kehidupan, yaitu memiliki rasa ingin tahu, perhatian, dan minat dalam mempelajari matematika, serta sikap ulet dan percaya diri dalam pemecahan masalah (Depdiknas, 2006). Terdapat beberapa kemampuan yang mampu membantu meningkatkan dan mengembangkan siswa dalam berfikir logis, rasional, sistematis, kritis dan kreatif, salah satunya adalah kemampuan representasi matematis.

Kemampuan representasi matematis adalah kemampuan menyajikan kembali notasi, simbol, tabel, gambar, grafik, diagram, persamaan atau ekspresi matematis lainnya ke dalam bentuk lain (Yudhanegara \& Lestari, 2015). National Council of Teacher of Mathematics (NCTM, 2000) menyatakan bahwa proses representasi melibatkan penerjemah masalah atau ide ke dalam bentuk baru. Representasi matematis akan membantu dalam memahami konsep dan prinsip matematika secara mendalam sehingga membantu dalam penyelasaian masalah matematika dan mengkomunikasikannya (Artiah \& Untarti, 2017). Kemampuan representasi matematis membantu siswa dalam memahami konsep matematika dan mengkomunikasikan ide-ide 
matematika. Sejalan dengan (Rahmadian et al., 2019) yang mengatakan bahwa representasi membantu siswa dalam meningkatkan pemahaman konsep matematika. Adapun beberapa bentuk representasi matematis seperti verbal, gambar, numerik, simbol aljabar, tabel, diagram, dan grafik merupakan bagian yang tak dapat dipisahkan dalam pembelajaran matematika. Rohmah dkk. (Rohmah et al., 2018) menyatakan bahwa kemampuan representasi merupakan kemampuan dasar yang harus dimiliki oleh siswa dalam mengemukakan ide-idenya dalam bentuk simbol-simbol, kata-kata atau grafik. Berdasarkan laporan hasil The Third International Mathematics and Science Study (Yudhanegara \& Lestari, 2015) diketahui bahwa: kemampuan siswa Sekolah Menengah Pertama di Indonesia dalam merepresentasikan ide atau konsep matematik dalam materi pembagian dan bilangan, aljabar, geometri, representasi data, analisis dan peluang termasuk rendah. Contoh, ketika siswa Indonesia diminta untuk membuat persamaan dari tabel yang merepresentasikan hubungan antara dua variabel, ternyata kemampuan representasi siswa Indonesia adalah $27 \%$ sedangkan kemampuan rata-rata internasional $45 \%$.

Hasil observasi dan wawancara dengan guru matematika SMP Negeri Kaliwungu tepatnya dikelas IXB dimulai pada tanggal 25 Juli 2020 hingga 17 Agustus 2020 mengungkapkan bahwa siswa masih mengalami kesulitan dalam membaca maupun menggambar grafik, selain itu juga dalam mengubah soal cerita ke dalam bentuk model matematika ataupun sebaliknya. Karena siswa mengalami kesulitan dalam mengerjakan hal-hal tersebut, sehingga banyak siswa yang hanya pasrah dalam mengerjakan soal latihan yang diberikan guru, ada yang menjawab langsung pada hasil akhirnya tanpa menuliskan cara yang digunakan, bahkan tidak sedikit yang menjawab asal-asalan saja. Selain itu ketika siswa menemukan soal yang dianggapnya sulit seketika pada saat itu juga siswa mengeluh tidak bisa mengerjakannya, hal ini mempengaruhi pikiran siswa sehingga motivasi siswa dalam mengerjakan soal menjadi berkurang.

Salah satu faktor yang mempengaruhi kemampuan representasi matematis siswa yaitu Self Efficacy siswa. Beberapa pakar mendefinisikan istilah Self Efficacy agak beragam, namun memiliki kesamaan ciri utama yaitu pandangan seseorang terhadap kemampuan dirinya (Hendriana \& Dkk, 2017). Menurut Bandura (Amir \& Risnawati, 2015), self-efficacy merupakan konstruksi sentral dalam teori kognitif sosial, yang dimiliki seseorang, dimakan akan: mempengaruhi pengambilan keputusannya, dan 
mempengaruhi tindakan yang akan dilakukannya; Membantu seberapa jauh upaya ia bertindak dalam suatu aktivitas; Mempengaruhi pola pikir dan reaksi emosionalnya. Niu (Niu, 2010) menyebut self efficacy adalah hasil interaksi antara lingkungan eksternal, mekanisme penyesuaian diri serta kemampuan personal, pengalaman dan pendidikan Dalam hal ini dapat dikatakan bahwa self-efficacy yang dimiliki masing-masing siswa dapat berpengaruh dalam upaya untuk mencapai hasil tertentu, dan juga tindakan siswa untuk menyelesaikan tugas-tugasnya. Sesuai dengan pendapat Zimmerman \& Schunk yang mengatakan siswa dengan self efficacy yang rendah akan menghindari tugas-tugas yang diberikan dalam proses belajar. Sedangkan siswa dengan self efficacy yang tinggi akan bersemangat dalam mengerjakan setiap tugas yang diberikan dalam proses belajar (Zimmerman \& Schunk, 2004).

Menurut Mukhid (Mukhid, 2009) Self-efficacy is judgement of a person to his acabilities to plan and implement the action to reach certain goals yang artinya Selfefficacy adalah penilaian seseorang terhadap kemampuannya merencanakan dan melaksanakan tindakan untuk mencapai tujuan tertentu. Menurut Alwisol (Alwisol, 2014) menyatakan bahwa efikasi diri adalah pandangan terhadap pertimbangan seseorang bahwa sesuatu itu baik atau buruk, tepat atau salah, mampu atau tidak mampu untuk dikerjakan sesuai dengan yang dipersyaratkan. Untuk itu dengan adanya Self Efficacy yang tinggi dalam diri siswa diharapkan dapat berhasil dalam memecahkan masalah matematika (Subaidi, 2016).

Berdasarkan uraian di atas, dilakukan penelitian berjudul "Profil Kemampuan Representasi Matematis Siswa SMP ditinjau dari Self Efficacy". Kemampuan representasi matematis dalam penelitian ditinjau dari 4 aspek yaitu aspek representasi visual, aspek representasi gambar, aspek representasi persamaan atau ekspresi matematis, dan aspek representasi kata atau teks Tertulis. Indikator kemampuan representasi dalam penelitian ini terdiri dari, 1. Menyajikan kembali data atau informasi dari suatu representasi ke representasi diagram, grafik, atau tabel; 2. Menggunakan representasi visual untuk menyelesaikan masalah; 3. Membuat gambar pola-pola geometri; 4. Membuat persamaan atau model matematis dari representasi lain yang diberikan; 5. Menulis interpretasi dari suatu representasi; 6. Menulis langkah-langkah penyelesaian masalah matematis dengan kata-kata, dan menjawab soal dengan menggunakan kata-kata atau teks tertulis. 


\section{METODE PENELITIAN}

Penelitian ini merupakan jenis penelitian kualitatif deskriptif. Penelitian ini dilaksanakan di SMP Negeri Kaliwungu tepatnya dikelas IXB dimulai pada tanggal 25 Juli 2020 hingga 17 Agustus 2020, dimana subjek penelitian sebanyak 26 siswa dimana nantinya dipilih tiga siswa dengan masing-masing siswa memilki self efficacy tinggi, self efficacy sedang, dan self efficacy rendah yang dipilih berdasarkan hasil skala self efficacy yang telah diisi. Indikator self efficacy yang digunakan dalam penelitian ini menurut Bandura (Hendriana \& Dkk, 2017) yang membagi menjadi tiga dimensi yaitu dimesi magnitude, dimensi generality, dan dimensi strength.

Langkah-langkah dalam penelitian ini adalah: tahap persiapan yaitu menyusun instrumen penelitian seperti kisi-kisi skala self efficacy, skala self efficacy berdasarkan skala yang disusun oleh Hendriana \& Dkk (2017), membuat soal dengan indikator kemampuan representasi matematis dan juga pedoman wawancara, kemudian melakukan validasi kepada para ahli. Tahap pelaksanaan yaitu memberikan skala self efficacy yang berupa google form kepada satu kelas, mengelompokkan siswa berdasarkan hasil skala self efficacy dengan kategori self efficacy tinggi, self efficacy sedang, dan self efficacy rendah, kemudian terpilih 3 subjek yaitu siswa yang memiliki self efficacy tinggi, sedang, rendah yang memiliki skor tertinggi dimasing-masing kategori untuk melakukan tes kemampuan representasi dan wawancara, setelah ini dilakukan analisis triangulasi berdasarkan hasil tes kemampuan representasi dan wawancara untuk menarik kesimpulan dari penelitian yang dilakukan dengan menjawab rumusan masalah. Soal terdiri dari tiga nomor dengan setiap nomor memuat satu indikator kemampuan representasi. Pada soal nomor satu memuat indikator representasi gambar, nomor dua memuat representasi simbol dan nomor tiga memuat representsi verbal. Pada penelitian ini menggunakan indikator kemampuan representasi kemampuan representasi matematis menurut Villegas (Triono, 2017). 


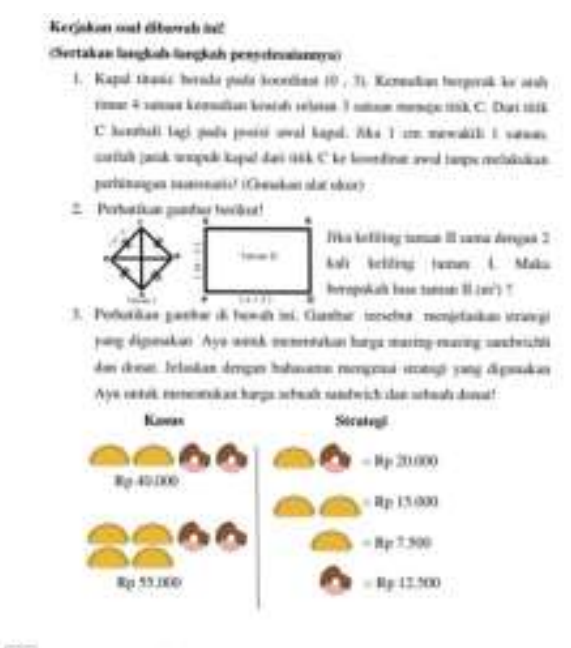

\section{Gambar 1. Soal Tes Kemampuan Representasi}

Klasifikasi kemampuan representasi dihitung menggunakan rumus menurut Djaali dan Mulyono (Armadan et al., 2017):

$$
N_{i}=\frac{X_{i}}{S_{i}} \times 100
$$

Keterangan:

$N_{i} \quad=$ Nilai kemampuan representasi

$X_{i} \quad=$ Jumlah skor yang diperoleh siswa

$S_{i} \quad=$ Jumlah skor maksimum

\section{HASIL DAN PEMBAHASAN}

Berdasarkan hasil analisis angket self efficacy mengelompokkan 26 siswa kelas IXB SMP Negeri 2 Kaliwungu menjadi tiga kategori yaitu 4 siswa self efficacy tinggi, 17 siswa self efficacy sedang, dan 5 siswa self efficacy rendah, disajikan pada tabel 1 sebagai berikut;

Tabel 1. Kategori Self Efficacy

\begin{tabular}{lcc}
\hline \multicolumn{1}{c}{ Kategori Self Efficacy } & Banyak Siswa & Persentase \\
\hline Self efficacy tinggi & 4 & 15,385 \\
Self efficacy sedang & 17 & 65,385 \\
Self efficacy rendah & 5 & 19,23 \\
\hline Jumlah & 26 & 100 \\
\hline
\end{tabular}


Berdasarkan hasil analisis tes self efficacy pada tabel 1, pemilihan subjek penelitian dipilih satu siswa dengan skor tertinggi dari masing-masing kategori untuk dianalisis kemampuan representasi matematisnya secara lebih lanjut. Tes soal kemampuan representasi matematis diberikan kepada tiga siswa yang sudah terpilih dan mewakili setiap tingkatan self efficacy. Dari hasil tes kemampuan representasi diperoleh:

\section{Kemampuan Representasi Siswa dengan Self Efficacy Tinggi}

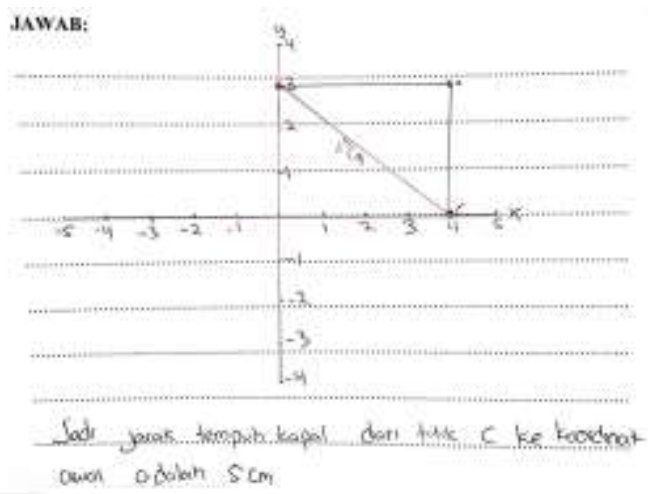

\section{Gambar 2. Jawaban Siswa dengan Self Efficacy Tinggi Pada Soal Nomor 1}

Siswa dengan self efficacy tinggi mampu mengubah representasi verbal kedalam representasi gambar dengan benar. Setiap detail yang diminta oleh soal dijawab dengan baik. Seperti menggambar koordinat cartesius lengkap dengan sumbu-x positif, sumbu$\mathrm{x}$ negatif, sumbu-y positif, dan sumbu-y negatif. Jarak yang digunakan dalam proses menggambar setiap titik pada koordinat kartesius juga sudah sama, karena jarak sangat berpengaruh dalam menjawab soal nomor 1 .

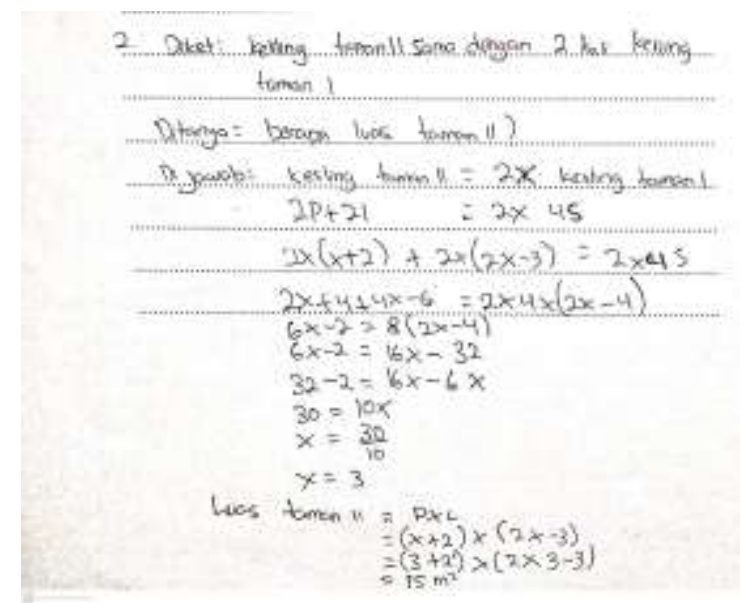

Gambar 3. Jawaban Siswa dengan Self Efficacy Tinggi Pada Soal Nomor 2

Siswa dengan self efficacy tinggi mampu merepresentasikan ulang dari representasi symbol ke representasi ekspresi model matematis. Setiap langkah ditulis 
dengan baik dan benar. Simbol yang digunakan pada soal menggunakan simbol variabel x. Pada penyelesaian soal nomor dua, Siswa dengan self efficacy tinggi mampu membuat persamaan dengan benar, serta mampu mengopersian variabel $\mathrm{x}$.

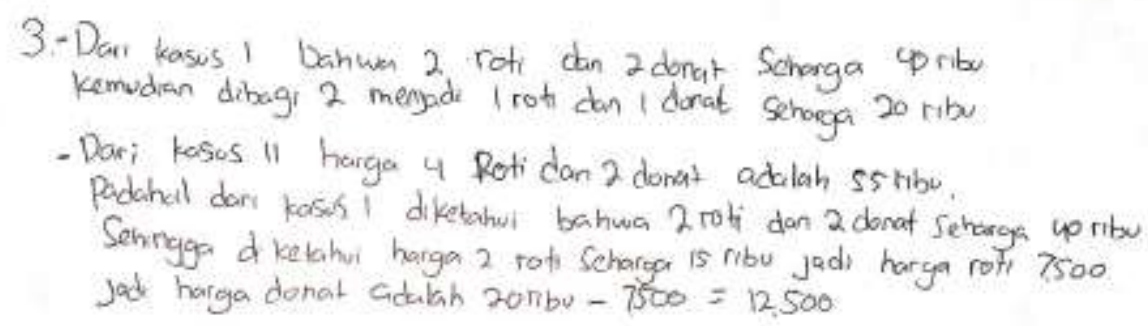

\section{Gambar 4. Jawaban Siswa dengan Self Efficacy Tinggi pada Soal Nomor 3}

Siswa dengan self efficacy tinggi mengubah representasi gambar kedalam representasi verbal kata-kata dengan benar. Dapat membaca ilustrasi gambar disoal dengan baik, terlihat dari kalimat yang disusun sesuai dengan jawaban yang diinginkan pada soal, tidak ada operasi matematika.

Siswa dengan self efficacy tinggi dapat menjawab ketiga soal dengan baik dan tepat. Hal ini menunjukan bahwa siswa mampu menggunakan representsi gambar, representasi simbol, dan representasi verbal. Hal ini dibuktikan bahwa siswa dapat membuat gambar untuk memperjelas masalah dan memfasilitasi penyelesaiannya, sehingga dapat menjawab soal dengan benar. Kemudian membuat persamaan atau model matematika dari permasalahan yang ada pada soal dan menjawabnya dengan benar. Selain itu dengan menyusun cerita yang sesuai permasalahan dalam soal dengan menggunakan kata-kata atau teks tertulis sehingga dapat menjawab dengan benar. Hal ini juga diuraikan pada hasil penelitian (Nadia \& Waluyo, 2017) bahwa siswa dengan self efficacy tinggi dapat menggunakan semua indikator kemamapuan representasi matematis dengan maksimal, sehingga mampu mengungkapkan ide-ide matematisnya dalam bentuk representasi matematis untuk menemukan solusi dari suatu persoalan dengan baik. Sesuai dengan hasil penelitian (Pratiwi et al., 2019) bahwa siswa dengan tingkat self-efficacy tinggi, memiliki kemampuan yang relatif mampu memahami konteks soal dalam menyajikan kembali informasi yang diperoleh dari soal kedalam bentuk representasi visual, verbal, dan simbol. Siswa yang self-efficacy tinggi memiliki ketercapaian kemampuan representasi tinggi. 


\section{Kemampuan Representasi Siswa dengan Self Efficacy Sedang}

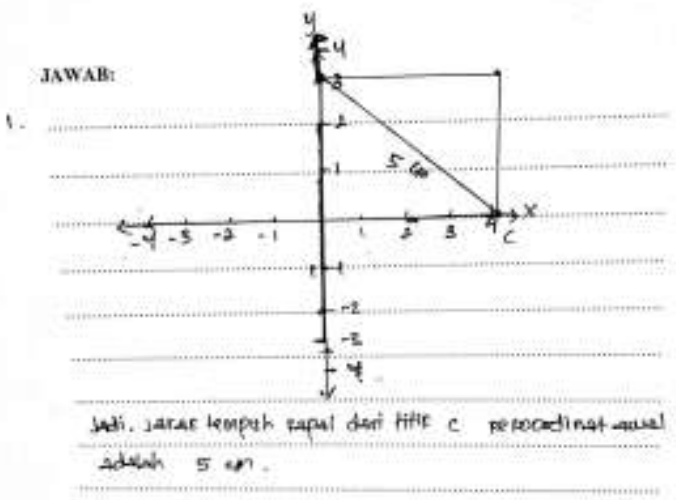

\section{Gambar 5. Jawaban Siswa dengan Self Efficacy Sedang pada Soal Nomor 1}

Siswa dengan self efficacy sedang menjawab soal nomor satu dengan benar. Terlihat pada gambar yang ada pada lembar jawab subjek AD, bahwa koordinat kartesius di buat dengan benar. setiap skala juga sama, selain itu sumbu-x dan sumbu-y juga lengkap. Sehingga siswa dengan self efficacy sedang dalam menjawab soal nomor 1 menggunakan alat ukur sudah tepat. Siswa dengan self efficacy sedang mampu memenuhi indikator kemampuan representasi visual yaitu membuat gambar atau grafik untuk menyelesaikan masalah yang diberikan.

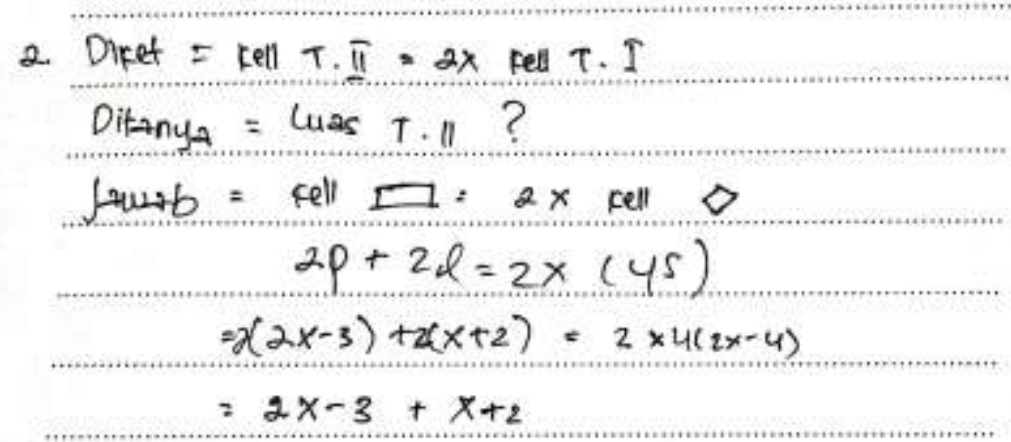

\section{Gambar 6. Jawaban Siswa dengan Self Efficacy Sedang pada Soal Nomor 2}

Siswa dengan self efficacy sedang menjawab soal nomor 2 mengalami kendala. Dalam mengaplikasikan pengetahuan yang diketahui yaitu rumus luas dan keliling bangun datar, siswa dengan self efficacy sedang mampu menuliskan rumus tersebut dengan benar. hanya saja karena pada soal nomor 2 terdapat variabel, ternyata siswa dengan self efficacy sedang mengalami kendala dalam pengoperasian variabel tersebut, sehingga siswa dengan self efficacy sedang dalam menjawab soal nomor 2 kurang 
lengkap namun sudah benar dalam setiap langkahnya. Siswa dengan self efficacy sedang belum mampu memenuhi indikator kemampuan representasi simbol karena masih belum bisa menggunakan secara maksimal persamaan ekspresi matematis yang telah dibuat untuk menyelesaikan masalah.

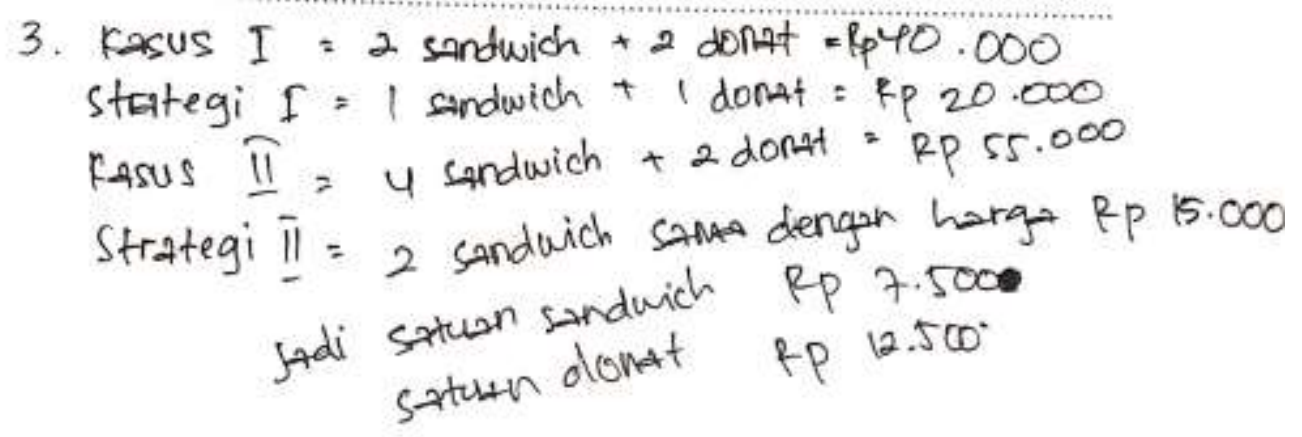

\section{Gambar 7. Jawaban Siswa dengan Self Efficacy Sedang pada Soal Nomor 3}

Diswa dengan self efficacy dalam menjawab soal nomor 3 belum menjelaskan langkah yang digunakan sehingga mendapatkan strategi seperti itu. Di samping itu, masih ada operasi matematika disana seperti tanda "+" dan "=", karena pada soal nomor 3 harus mengutarakan strategi dalam bentuk verbal. Siswa dengan self efficacy sedang belum mampu memenuhi indikator kemampuan representasi verbal karena masih belum bisa menggunakan secara maksimal dalam mengungkapkan jawaban dalam bentuk katakata.

Siswa dengan self efficacy sedang dapat menjawab soal representasi gambar dengan baik dan tepat. Namun untuk representasi simbol, siswa mampu membuat persamaan atau model matematika hanya saja belum bisa menyelesaikan permasalahan yang melibatkan ekspresi matematika. Sedangkan untuk representasi verbal, siswa belum sepenuhnya menceritakan jawaban pada permasalahan di soal, masih ada beberapa langkah yang terlewat. Hal ini juga diuraikan pada hasil penelitian (Nadia \& Waluyo, 2017) bahwa siswa dengan self efficacy sedang dapat menggunakan semua indikator representasi matematis meskipun juga masih kurang maksimal. Siswa dengan tingkat self-efficacy sedang, memiliki kesulitan dalam menyelesaikan soal, sehingga jawaban yang diberikan tidak lengkap dan kurang tepat dengan informasi yang terdapat pada soal. Hal tersebut juga diungkapkan (Pratiwi et al., 2019) pada hasil penelitiannya, bahwa siswa dengan tingkat self-efficacy sedang, memiliki kesulitan dalam menyelesaikan soal, sehingga jawaban yang diberikan tidak lengkap dan kurang tepat 
dengan informasi yang terdapat pada soal.

\section{Kemampuan Representasi Siswa dengan Self Efficacy Rendah}

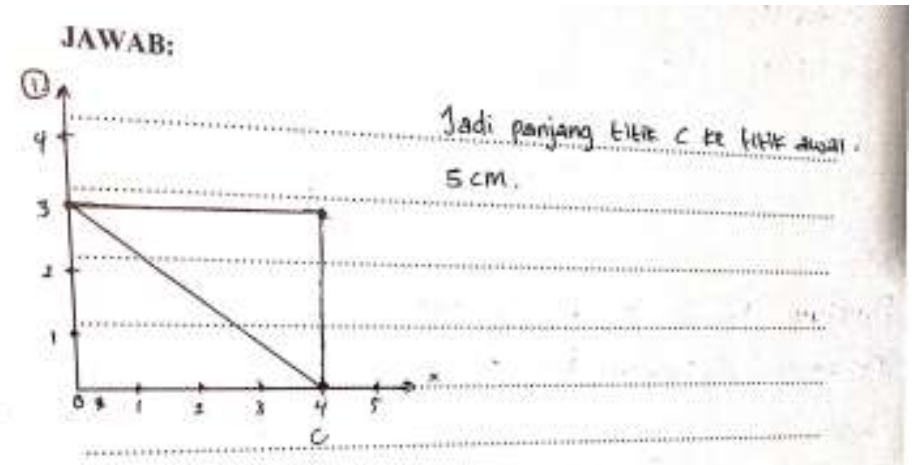

\section{Gambar 8. Jawaban Siswa dengan Self Efficacy Rendah pada Soal Nomor 1}

Siswa dengan self efficacy rendah dalam menjawab soal nomor 1 sudah benar, hanya saja kurang lengkap dalam menggambar koordinat kartesius. Pada koordinat kartesius memiliki sumbu-x negatif dan sumbu- y negatif, namun subjek YS tidak menggambar sumbu tersebut. Selain itu belum lengkap juga dalam menuliskan keterangan mana yang merupakan sumbu-y. Siswa dengan self efficacy rendah belum maksimal dalam memenuhi indikator kemampuan representasi matematis visual karena masih terdapat kesalahan-kesalahan dalam proses menggambar.

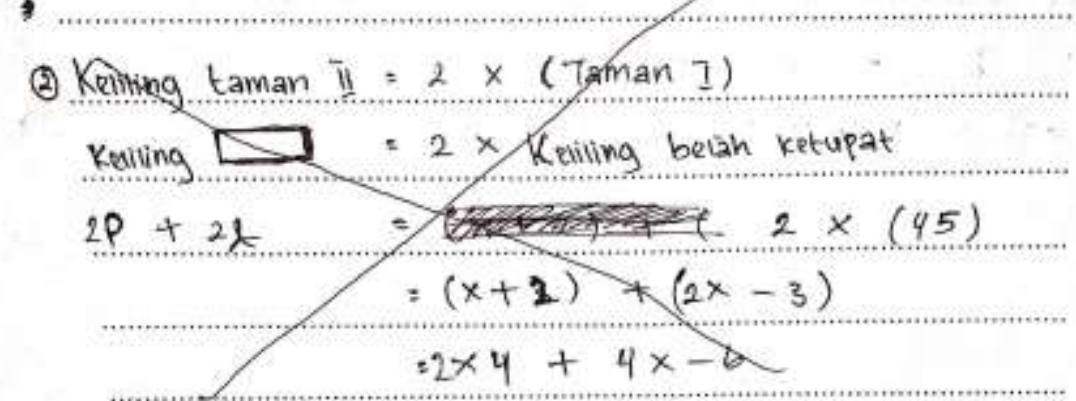

Gambar 9. Jawaban Siswa dengan Self Efficacy Rendah pada Soal Nomor 2 (a) 
(2) Dikeraui Taman if $=2 \times$ (Taman 3)

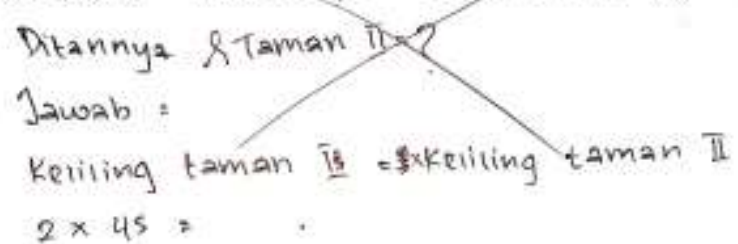

Gambar 10. Jawaban Siswa dengan Self Efficacy Rendah pada Soal Nomor 2 (b)

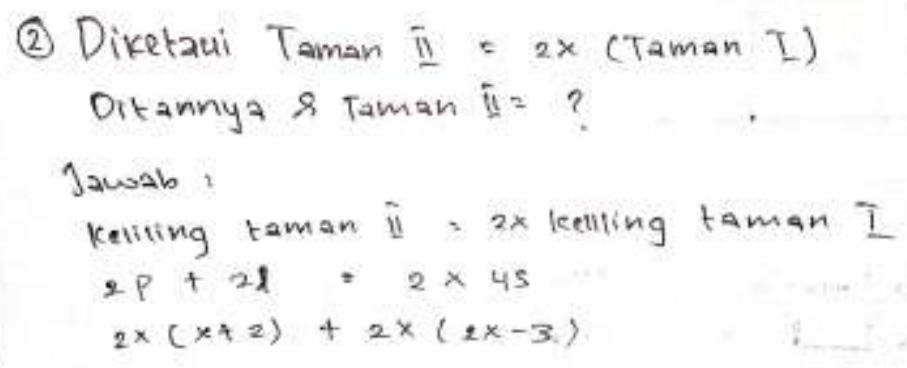

Gambar 11. Jawaban Siswa dengan Self Efficacy Rendah pada Soal Nomor 2 (c)

Siswa dengan self efficacy rendah dalam menjawab soal nomor 2 mengalami kendala. Terlihat pada gambar 9, gambar 10, dan gambar 11 dimana iswa dengan self efficacy rendah menjawab berkali - kali soal nomor 2, namun belum juga menemukan jawaban akhir. Pada langkah awal menuliskan persamaan sudah benar, hanya saja pada langkah mensubstitusikan iswa dengan self efficacy rendah kengingungan, sehingga pada proses pengoperasian juga mengalami kendala. Siswa dengan self efficacy rendah belum mampu memenuhi indikator kemampuan representasi matematis simbol karena belum bisa mmbuat persamaan ekspresi matematis untuk memfasilitasi dalam menyelesaikan masalah.

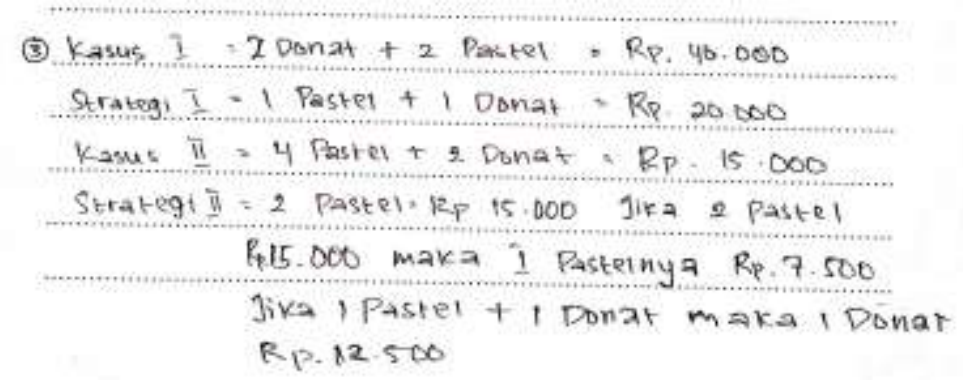

Gambar 12. Jawaban Siswa dengan Self Efficacy Rendah pada Soal Nomor 3 Siswa dengan self efficacy rendahdalam menjawab soal nomor 3 belum 
menjelaskan langkah yang digunakan sehingga mendapatkan strategi seperti itu. Di samping itu, masih ada operasi matematika disana seperti tanda "+" dan "=", karena pada soal nomor 3 harus mengutarakan strategi dalam bentuk verbal. Selain itu, iswa dengan self efficacy rendah juga salah menuliskan harga empat pastel dan dua donat, dan masih ada langkah yang terlewat. Siswa dengan self efficacy rendah belum maksimal dalam memenuhi indikator kemampuan representasi matematis verbal karena masih terdapat kesalahan dan langkah yang terlewat.

Siswa dengan self efficacy rendah dapat menjawab soal representasi gambar dengan baik dan tepat, meskipun pada gambar masih ada beberapa hal yang belum lengkap. Namun untuk representasi simbol, siswa belum bisa membuat persamaan atau model matematika sehingga belum bisa menyelesaikan permasalahan yang melibatkan ekspresi matematika. Sedangkan untuk representasi verbal, siswa belum sepenuhnya menceritakan jawaban pada permasalahan di soal, masih ada beberapa langkah yang terlewat.

Kriteria penskoran kemampuan representasi matematis siswa, disajikan dalam tabel sebagai berikut:

Tabel 2. Kategori Kemampuan Representasi

\begin{tabular}{cc}
\hline Skor & Kategori \\
\hline $86-100$ & Tinggi \\
$71-85$ & Sedang \\
$56-70$ & Rendah \\
$0-55$ & Kurang \\
\hline
\end{tabular}

Nilai kemampuan representasi yang didapatkan oleh siswa dengan self efficacy tinggi yaitu 100, siswa dengan self efficacy sedang yaitu 75, siswa dengan self efficacy rendah yaitu 58,33. Berdasarkan tabel 2: siswa dengan self efficacy tinggi termasuk dalam kategori tinggi, siswa dengan self efficacy sedang termasuk dalam kategori sedang, siswa dengan self efficacy rendah termasuk dalam kategori rendah.

Hal ini sejalan dengan teori yang dinyatakan oleh Albert Bandura (Amir \& Risnawati, 2015) mengatakan bahwa Self Efficacy seseorang akan mempengaruhi tindakan, upaya, ketekunan, fleksibilitas dalam perbedaan, dan realisasi dari tujuan, dari individu ini, sehingga Self Efficacy yang terkait dengan kemampuan seseorang seringkali menentukan outcome sebelum tindakan terjadi, dan juga self-efficacy berperan dalam tingkatan pencapaian yang akan diperoleh seseorang dan self-efficacy 
juga berakibat pada suatu tindakan manusia melalui proses motivasional, kognitif, dan afektif. Self-efficacy akan tampak berdasarkan usaha yang dilakukan sesorang melalui proses tertentu bukan terbentuk dengan sendirinya, ada beberapa tahapan-tahapan tertentu yang harus dilalui oleh individu sehingga dapat menyakini kemampuan mereka terhadap kegiatan pembelajaran maupun tugas-tugas tertentu yang akan mereka lakukan.

\section{SIMPULAN}

Berdasarkan uraian deskripsi data serta analisis data dapa disimpulkan bahwa siswa dengan self efficacy tinggi mempunyai kemampuan representasi tinggi, siswa dengan self efficacy sedang mempunyai kemampuan representasi sedang, dan siswa dengan self efficacy rendah mempunyai kemampuan representasi rendah. Siswa dengan self efficacy tinggi dapat menggunakan semua indikator representasi matematis dengan maksimal, mampu mengungkapkan ide-ide matematisnya dalam tiga representasi yaitu gambar, simbol dan verbal untuk menyelesaikan masalah dari suatu persoalan. Siswa dengan self efficacy sedang dapat menggunakan semua indikator representasi matematis namum belum maksimal. Pada representasi simbol, siswa belum mampu menyelesaikan masalah yang melibatkan persamaan atau model matematika. Di samping itu, pada representasi verbal juga masih ada beberapa langkah yang terlewat sehingga belum maksimal menjawab soal dalam bentuk kata-kata atau teks tertulis. Siswa dengan self efficacy rendah dapat menggunakan representasi gambar dengan baik meski masih ada beberapa detail yang kurang lengkap. Namun belum mampu mencapai indikator kemampuan representasi matematis simbol dan verbal, siswa masih kesulitan dalam menentukan langkah-langkah penyelesaian, siswa juga masih kebingungan untuk menyelesaikan permasalahan dari langkah-langkah yang sudah dibuat dikarenakan terkadang siswa merasa lupa dengan rumus yang harus digunakan. 


\section{DAFTAR PUSTAKA}

Alwisol. (2014). Psikologi Kepribadian Edisi Revisi. Malang: UMM Press.

Amir, Z., \& Risnawati. (2015). Psikologi Pembelajaran Matematika. Aswaja PressindoYogyakarta.

Annajmi. (2016). Peningkatan Kemampuan Representasi Matematik Siswa Smp Melalui Metode Penemuan Terbimbing Berbantuan Software Geogebra Di Smp N 25 Pekanbaru. Jurnal Ilmiah Edu Research, 5(2), 67-74.

Armadan, A., Somakim, S., \& Indaryanti, I. (2017). Kemampuan Representasi Matematis Siswa pada Pembelajaran Berbasis Teori Van Hiele di Materi Segiempat Kelas VII SMP Negeri 1 Indralaya Utara. Jurnal Elemen, 3(1), 49. https://doi.org/10.29408/jel.v3i1.306

Artiah, \& Untarti, R. (2017). Pengaruh Model Reciprocal Teaching Terhadap Kemampuan Representasi Matematis Siswa Kelas Vii Smp Negeri 6 Purwokerto. AlphaMath, 3(1), 1-11.

Depdiknas. (2006). Standar Isi untuk Satuan Pendidikan Dasar dan Menengah, SK dan KD SMP/MTs. Jakarta: BNSP.

Hendriana, \& Dkk. (2017). Hard Skills dan Soft Skills Matematik Siswa. Bandung: PT. Refika Aditama.

Mukhid, A. (2009). SELF-EFFICACY (Perspektif Teori Kognitif Sosial dan Implikasinya terhadap Pendidikan). Tadrîs Jurnal Pendidikan Islam, 4(1), 116122. https://doi.org/10.1109/HiPINEB.2018.00011

Nadia, L. N., \& Waluyo, S. T. B. (2017). Analisis Kemampuan Representasi Matematis Ditinjau dari Self Efficacy Peserta Didik melalui Inductive Discovery Learning. Unnes Journal of Mathematics Education Research, 6(2), 242-250.

NCTM. (2000). Principles and Standards for School Mathematics. Reston: The National Council of Teachers of Mathematics. Inc.

Niu, H. J. (2010). Investigating the effects of self-efficacy on foodservice industry employees' career commitment. International Journal of Hospitality Management, 29(4), 743-750. https://doi.org/10.1016/j.ijhm.2010.03.006

Pratiwi, N. K. A., Yusmin, E., \& Yani, A. (2019). KEMAMPUAN REPRESENTASI MATEMATIS MENYELESAIKAN SOAL SEGI EMPAT DITINJAU DARI SELF-EFFICACY DI MADRASAH TSANAWIYAH. Jurnal Pendidikan Dan $\begin{array}{ll}\text { Pembelajaran } \quad \text { Khatulistiwa, } & \text { 8(9). }\end{array}$ https://jurnal.untan.ac.id/index.php/jpdpb/article/view/36087

Rahmadian, N., Mulyono, \& Isnarto. (2019). Kemampuan Representasi Matematis dalam Model Pembelajaran Somatic, Auditory, Visualization, Intellectually (SAVI) | PRISMA, Prosiding Seminar Nasional Matematika. PRISMA, Prosiding Seminar Nasional Matematika, 2, 287-292. https://journal.unnes.ac.id/sju/index.php/prisma/article/view/28940

Rohmah, A. S., Rohaeti, E. E., \& Afrilianto, M. (2018). Kemampuan Representasi Matematis Siswa SMP Kelas VIII pada Materi Sistem Persamaan Linear Dua Variabel dengan Pendekatan Kontekstual. SOSIOHUMANIORA: Jurnal Ilmiah 
Ilmu Sosial Dan Humaniora, 4(1), 51-62. https://doi.org/10.30738/sosio.v4i1.2280

Subaidi, A. (2016). Self-Efficacy Siswa Dalam Pemecahan Masalah Matematika. Jurnal Eigma. Universitas Madura, 1(2), 64-68.

Suyitno, H. (2016). Pengantar Filsafat Matematika (p. 11). Yogyakarta: Magnum Pustaka Utama.

Triono, A. (2017). ANALISIS KEMAMPUAN REPRESENTASI MATEMATIS SISWA KELAS VIII SMP NEGERI 3 TANGERANG SELATAN. In SKRIPSI (p. 107). repository.uinjkt.ac.id.

Yudhanegara, M. R., \& Lestari, K. E. (2015). Meningkatkan Kemampuan Representasi Beragam Matematis Siswa melalui Pembeajaran Berbasis Masalah Terbuka (Penelitian Kuasi Eksperimen terhadap Siswa Kelas VII SMPN 1 Pagaden, Subang). Jurnal Ilmiah Solusi, 1(4), 97-106.

Zimmerman, B. J., \& Schunk, D. H. (2004). Self-regulating intellectual processes and outcomes: A social cognitive perspective. In D. Y. Dai \& R. J. Sternberg (Eds.), The educational psychology series. Motivation, emotion, and cognition: Integrative perspectives on intellectual functioning and dev. Lawrence Erlbaum Associates Publishers., 323-349. 